\title{
The Interpretation of Indirect Utterances by Egyptian Learners of EFL: \\ A Comparative Developmental Study \\ By
}

\section{Negm}

This paper asserts the importance of sommunicative competence in learning and teaching English as a foreign language. It discusses one aspect of communicative competence: the interpretation of indirect utterances. Two pragmatic notions that relate to udirectness studied in this paper are: implicature and pragmatic ambivalence. A test that measures the carners' ability to interpret implicature and pragmatic ambivalence was administered to two groups: first year and fourth year students in the English department, the

- Faculty of Arts, Tanta University. The results strongly

- suggest that learners' competence in interpreting indirect utterances improves in this respect. This improvement can be attributed to the courses in pragmatics,

$I$ conversation and literature that learners are exposed to in the course of four years of study in the English department. The study strongly recommends more intensive and extensive study of language forms in 
context. It also emphasizes that learners' attention should be drawn to the multiplicity of interpretations an utterance may have in a certain context.

\section{Prolegomenon}

Until recently, linguistics concentrated solely on the analysis of the formal aspect of language. In this context, Littlewood (1981:24) argues that the structural view of language that was prevalent until recently focuses on the grammatical system, confining itself to the description of ways in which linguistic items can be combined. Yule (1996:6) expresses a similar view when he contends that "for a long period in the study of language, there has been a very strong interest in formal systems of analysis, often derived from mathematics and logic. The emphasis has been on discovering some of the abstract principles that lie at the very core of language." Likewise, Rizk (1997:1) argues that in the area of language analysis and research, grammatical rules and :linguistic competence "have been given the most attention at the expense of sociolinguistic and sociocultural competence." 
The emphasis on form in linguistic analysis was , also reflected in language teaching. Thus, Fouly et al (1990) contend that the structural view of language equated learning a second or foreign language with mastering its formal elements or components. Moreover,

- Croft (1980:10) argues in this context that "the structural syllabus underlies a good deal (perhaps most) of the teaching aids used today. Materials are selected in reference to the grammatical components and rules of the language. Similarly, Savignon (1993:35) believes that until recently, American structural linguistics was "the prevailing influence in language teaching methods and materials." Rizk (1997:1) also remarks that "the problem with most English as a foreign / second language (EFL / ESL) textbooks and syllabi is their emphasis on grammatical, phonological and semantic aspects, paying very little attention to cultural or social aspects."

However, Croft (1980:6) stresses that "linguistic competence is not enough for practical or educational purposes. To be effective in the use of language, a person must not only know the language but also how to use it. This proves, as Hicks (1992:66) argues, the limitations of the Chomskyan concept of knowing language that fails 
to assert the sociocultural aspect of language use. Thus, Scarella et al (1992:68) argue that "before the mid1960 s, competence in a language was defined narrowly. in terms of its grammatical knowledge."(1) Along the same lines, Littlewood (1981:24) emphasizes that the structural view of language is not "sufficient on its own to account for how language is used as a means of * communication.

In short, formal approaches to language learning were keen on developing only one aspect of * communicative competence. Knowledge of rules was the main objective of language courses. On the contrary, recent approaches stress both the formal and the communicative. As Sasaki (1998) has put it "recent models of communicative competence comprise both formal and functional aspects of language." Bachman . (1989) views second language competence as consisting . of two main components: organizational and pragmatic. Organizational competence consists of those abilities involved in controlling the formal organization of language. Pragmatic competence includes sociolinguistic ${ }^{\text {* }}$ and socio-cultural elements. Bachman (1990) sees the .formal and the functional as complementary. Canale's 
(1983) model of communicative competence expands the model of second language proficiency to include sociolinguistic, discursive and strategic competencies as well. Croft (1980) and Spolsky, among many, see communicative goals to be ordinarily sought by second language learners." And Brumfit (1984:24) emphasizes that "there is general agreement among applied linguists that it is necessary to specify as clearly as possible not only the formal features of linguistic system but the ways in which these formal features may legitimately be operated."

A pragmatic notion that shows the relation between the formal features of a language and its use is indirectness. However, Sasaki (1998:458) rightly argues that "although several measures have been developed to test the formal aspects of second language (L,2) competence, very few ${ }^{(2)}$ have been developed to assess functional aspects." (3) To be more specific, few studies in

$\because \quad F L$ discourse address the notion of indirectness. Boutom

* (1988) compared the ability of native speakers (NS) and (NNS) to interpret implicature in English and found that the two groups interpreted the same implicature in the same context in the same way only $75 \%$ of the time. 
Similarly, Bouton (1991) found that NN speakers' interpretation of implicature differed from natives. Finally, Bouton (1992) concluded that "even NNS who have achieved a proficiency in English that can be represented by a score in the mid -500's on the TOEFL differed from NS in their interpretation for some $25 \%$ of the items used in this study. Furthermore, a comparison of the interpretation assigned to these implicatures by the American NS with those of British and Canadian NS turned up no significant differences in the messages these groups derived, but all three groups of NS differed significantly from the NNS .

\section{Problem}

The present paper studies discourse as the interaction of form and function. It measures one aspect of communicative competence: the ability to interpret indirect utterances. Indirectness is the result of the fact that, there is a gap between what is spoken or written and what is meant (Stubbs: 1983).

This paper attempts to find to what extent students communicative competence develops in the course of three years of study in the English department, Faculty of Arts, Tanta University. In short, this study examines the 
effect of the courses taught during 3 years of study on developing communicative competence. Indirectness is seen in the context of this study as a case where the jiteral and the intended are not identical.

The question that is addressed in the context of this - study is: are the courses taught in the faculties of arts effective or not in developing functional aspects of language? In short, Does the communicative competence of students develop or not in the course of 3 years of study?

\section{Theoretical Preliminaries}

Two types of indirectness are addressed: pragmatic ambivalence and implicature.

\section{I.1. PRAGMATIC AMBIVALENCE}

Pragmatic ambivalence occurs, as Thomas (1995:195) argues, when the intended force of an utterance such as "is that the phone?" is quite indeterminate. This is by virtue of the fact that it can be either a straightforward question or a request to the 
hearer to answer the phone. Thus, pragmatic ambivalence is used when the speaker does not "make clear precisely which range of related illocutionary values is intended." In other words, it is a case where the same utterance or speech act can be used for more than one discourse function. For example an utterance like "it is cold in here" can be used as a constative (report about the temperature in the room), a request to turn on the heating system, or an excuse to leave the room.

Thomas (1988) distinguishes between ambiguity and ambivalence. Ambiguity is a semantic grammatical term. It is the case that the speaker intends more than one meaning. With ambivalence, which operates at a pragmatic level, both speaker and addressee understand that more than one interpretation is possible. Coates' notion of indeterminacy refers to the same phenomenon.

Di Pietro (1988:8) uses the term transactional ambiguity to refer to indeterminacy in reference to the intent of what is said. In this case, we "delve beneath the meanings of the words and their grammatical . arrangement to investigate the purposes that the speakers 
may be attaching to each other." As Di Pietro continues:

\begin{abstract}
In natural discourse, each participant is led to attach meanings to utterances beyond the meaning of their factual content. The statement "It's cold in here" may be a simple acknowledgment of a state of affairs, but intent of the person who made the declaration is open to interpretation by those who hear it. Perhaps the speaker would like to be given a sweater. Perhaps the speaker's intent is to have someone turn up the heat.
\end{abstract}

Furthermore, Di Pietro admits that there can be other potential transactional interpretations, depending on what experience has been shared by the speakers and what the hearers decide is the proper one. ${ }^{(4)}$

\title{
I.2. Implicature:
}

Yule (1996:36) defines implicature as an "additional conveyed meaning." Implicatures are thus "examples of more being communicated than is said." Green (1989) argues that "much of the value of implicature in conversation lies in its indirectness, in the fact that it allows the speaker to avoid saying exactly what she means to convey." 
- Yule continues to argue that "the concept of there being an expected amount of information provided in conversation is just one aspect of the more general idea that people involved in a conversation will cooperate with each other." Moreover, Green (1989:91) argues that "implicatures are likely to arise or to be intended whenever a maxim appears to be conspicuously violated, whether the violation is real or only apparent, and whether or not the maxim is sacrificed for another maxim." In this context Grice's cooperative principle should be referred to since, as Yule argues (p.36), in order to interpret implicature "some basic cooperative principle must first be assumed to be in operation."

\section{The cooperative principle}

In his (1975) influential article, Grice proposes a . cooperative principle and four associated maxims. Grice (p.45) states the CP as follows:

make your conversational contribution such as is required at the stage at which it occurs, by the accepted purpose or direction of the talk exchange in which you are engaged. 
In addition, Grice (pp. 45-46) proposes the following four maxims:

- (1) the maxim of quantity.

(2) the maxim of quality.

(3) the maxim of relation.

(4) the maxim of manner.

Grice refers in his model to one type of indirectness and hence implicature which is created when the speaker does not observe any of the maxims. As Grice continues to argue (p.45) apparent violations of the $C P$ are taken as conversational implicature.

Grice discusses two types of implicature: conversational implicature and conventional implicature.

\section{CONVERSATIONAL IMPLICATURE}

Following Grice, Yule classifies CONVERSATIONAL IMPLICATURE into: generalized and particularized conversational implicatures. In generalized

- sonversational implicature "no special background knowledge of the context of utterance is required in order to make inference necessary." An example provided by Yule is: 
Doobie: Did you invite Bella and Cathy?

Mary : I invited Bella.

Without special knowledge, one can infer from Mary's reply that she did not invite Cathy.

Particularized conversational implicature takes place in "very specific contexts in which locally recognized inferences are assumed. An example provided by Yule is:

Rick : Hey, coming to the wild party tonight?

Tom : My parents are visiting.

In order to make sense of Tom's reply, Rick has to draw on some assumed knowledge that one college student in this setting expects his parents to visit. In this case, he is ' assumed not to leave his parents and go to the party.

\section{Conventional implicatures are non-truth.} conditional inferences that are not derived from the CP. As Green (1989:94) argues "conventional implicatures differ from conversational implicatures in that conventional implicatures do not crucially depend on 
assuming the speaker to be observing the Cooperative principle." Yule supports the same contention arguing $t^{\text {L }}$ at Conventional implicatures are not based on the choperative principle. Moreover, as Yule continues -(p.44) to argue "they do not have to occur in conversation, and they don't depend on special contexts for their interpretation. Words such as "but," "yet," "even" and so on have conventional implicature. For example, "yet" has the conventional implicature that "the present situation is expected to be different or perhaps the opposite, at a later time."

Blakemore (1992:127) discusses another type of implicature called "bridging implicatures." These are "implicatures of a referring expression in a following utterance." The hearer of (12) and (13) will supply the contextual assumptions in (14) without previous knowledge of the number of lights in the room:

(12) (a) She went into the room:

(b) the light was on.

- (15) (a) She went into the room

(b) Both of the lights were on.

(14) the room had a light the room had two lights 


\section{METHOD}

\section{II.1. Subjects}

To implement this study, the subjects were taker from English department students in the faculty of Arts, Tanta University. The sample included one hundred seventy students in the first year, (males and females) and one hundred seventy students in the fourth year, also males and females. They were randomly selected. These two levels were used to investigate the effect of the literature and language courses on developing the functional aspect of language.

\section{II.2 Instrument.}

The test is an indirectness interpretation test. It is a multiple-choice instrument consisting of 60 items. Except for item II. 5, the test items are devised by the author. Each item consists of a brief description of a . situation with a short dialogue followed by a question.

The test has two main parts: pragmatic : ambivalence, and implicature. The first part of the test includes 4 sections each comprising 10 items: requests, . excuses, invitations and warnings. The second part of the test comprises 20 items, which are supposed to measure instances of implicature. Different types of implicature 
relating to the four maxims of Grice are covered. However, much emphasis has been placed on the maxim tof relation since it has conventionally received the - greatest attention in pragmatics. For example Sperber and Wilson (1986) used it as the basis for their theory of

- relevance.

Having developed a tentative version of the twopart test, a pilot study was conducted applying the test with the purpose of examining the effectiveness of its distracters. The avoided ones had been excluded and substituted by others more capable of attracting students' attention.

\section{Test Validity}

Test validity was achieved in two ways: making a content analysis of the test items and by submitting the test to a number of academic judges/advisors whose feedback regarding the test purpose and construction was taken into consideration. Accordingly, a number of items were reshaped and others were excluded to secure attaining the objectives of the test. See appendix 1 for the test. 


\section{II.3. Procedure}

The test was administered to the two groups of students independently towards the end of the secon term, (April, 1999). The test took around one hour in each group, in two sessions with a five-minute break between the two sub-tests.

\section{Research Hypotheses}

The following hypotheses were formulated:

1-There would be statistically significant differences between first and fourth year students' scores on the 'Request' section of the test in favor of the fourth year group.

2- There would be statistically significant differences between first and fourth year students scores on the 'Excuses' section of the test in favor of the fourth year group.

3- There would be statistically significant differences between first and fourth year students scores on the 'Offers and Invitation' section of the test in favor of the fourth year group.

4- There would be statistically significant differences between first and fourth year students scores on the 
'Warning' section of the test in favor of the fourth year group.

5- There would be statistically significant differences between first and fourth year students scores on the 'Total pragmatic ambivalence part of the test in favor of the fourth year group.

6- There would be statistically significant differences between first and fourth year students scores on the 'Implicature' part of the test in favor of the fourth year group.

7- There would be statistically significant differences between first and fourth year students scores on the 'Total indirectness interpretation test' in favor of the fourth year group.

\section{Results}

The scores obtained were subjected to statistical treatment. Using the SPSS program, data were treated by the $\mathrm{t}$-test to find whether the hypotheses were supported

- $\quad$ or rejected and see whether the differences in scores

- between the two groups are statistically significant or not. The results of each part of the test will be dealt with separately. 


\section{Pragmatic Ambivalence}

To find if there are significant differences between first and fourth year students, in the first part of the test, the following table was obtained. Table 1 shows the mean, standard deviation and the $t$-value for each question (or speech act) as well as the total scores for part I (Pragmatic Ambivalence.)

\section{Table 1}

t-test for first and fourth year on Pragmatic

Ambivalence

\begin{tabular}{|c|c|c|c|c|c|c|}
\hline Component & group & $\mathrm{N}$ & $\mathrm{M}$ & $\mathrm{SD}$ & t-value & $\begin{array}{c}\text { 2-tail } \\
\text { significance }\end{array}$ \\
\hline Requests & $1^{\text {st }}$ & 170 & 7.4706 & 1.496 & 5.97 & .000 \\
& $4^{\text {th }}$ & 170 & 8.3882 & 1.333 & & .000 \\
\hline Excuses & $1^{\text {st }}$ & 170 & 5.6412 & 2.592 & 4.60 & .000 \\
& $4^{\text {th }}$ & 170 & 6.6941 & 1.484 & & .000 \\
\hline Offers and & $1^{\text {st }}$ & 170 & 6.6249 & 1.201 & \multirow{2}{*}{2.14} & .000 \\
Invitations & $4^{\text {th }}$ & 170 & 6.9000 & 1.134 & & .000 \\
\hline Warning & $1^{\text {st }}$ & 170 & 7.5882 & 1.984 & \multirow{6}{*}{6.18} & .000 \\
& $4^{\text {th }}$ & 170 & 8.7529 & 1.499 & & .000 \\
\hline Total & $1^{\text {st }}$ & 170 & 27.3294 & 4.472 & 7.80 & .000 \\
& $4^{\text {th }}$ & 170 & 30.7353 & 3.526 & & .000 \\
\hline
\end{tabular}

As table 1 shows, there are high significant mean differences between $1^{\text {st }}$ year group and $4^{\text {th }}$ year group in favor of the fourth year on each of the four components 
of the pragmatic ambivalence sub-test as well as on the total score. So, the first 5 hypotheses were supported.

\section{Implicature}

To find if there are significant differences between first and fourth year students, in the second part of the test, the following table was obtained. Table 2 shows the mean, standard deviation and the $t$-value for each question

\section{Table 2}

Means, SD and t-value

For Implicature

\begin{tabular}{|c|c|c|c|c|c|c|}
\hline Component & Group & $\mathrm{N}$ & $\mathrm{M}$ & $\mathrm{SD}$ & $\mathrm{t}$-value & $\begin{array}{c}\text { 2-tail } \\
\text { significance }\end{array}$ \\
\hline Implicature & $1^{\text {st }}$ & 170 & 14.6471 & 2.007 & 4.78 & .000 \\
& $4^{\text {th }}$ & 170 & 15.7471 & 2.232 & .000 \\
\hline
\end{tabular}

As table 2 shows, there is a high statistical significant difference in favor of the second group on implicature.

- zo the sixth hypothesis was supported.

Indirectness (Pragmatic Ambivalence and implicature)

Finally, to find if there are significant differences between first and fourth year students, in the test, as a whole, the following table was obtained. Table 3 shows 
the mean, standard deviation and the t-value for the test, as a whole.

\section{Table 3}

Means, SD and t-value for total score

\begin{tabular}{|c|c|c|c|c|c|c|}
\hline Component & Group & $\mathrm{N}$ & $\mathrm{M}$ & $\mathrm{SD}$ & $\mathrm{t}$-value & $\begin{array}{c}\text { 2-tail } \\
\text { significance }\end{array}$ \\
\hline Total & $1^{\text {st }}$ & 170 & 46.4824 & 5.253 & 8.23 & .000 \\
Score & $4^{\text {th }}$ & 170 & 41.9765 & 4.834 & .000 \\
\hline
\end{tabular}

As table 3 shows, there is a high statistical significant difference on the scores of the test as a whole in favor of the second group. This means that the students of the fourth year have not only improved on the different parts of the test but also on the test as a whole, that is, in the interpretation of indirect utterances.

\section{Interpretation}

Learners have shown improvement in the interpretation of indirect utterances. On the whole, improvement in interpreting indirect utterances is due to the fact that in the course of their four years of study, " they are exposed to courses in literature and linguistics. In linguistics, they study traditional grammar, . conversation, semantics and pragmatics. 
2 I have opted to start with pragmatics because its main goal is to study language in use. It studies language forms in relation to the context in which they are deployed. To be specific, pragmatics studies language as goal-directed actions. Moreover, topics such as implicature, indirect speech acts, pragmatic ambivalence and discourse ambivalence are usually covered in a course on pragmatics. In other words, pragmatic analysis offers students the chance to study language as function. The present study shows that pragmatics enriches student's understanding and interpretation of language forms in the context in which they occur. This entails that in a pragmatics course, attention should not only be focused on theoretical notions but also on situations, which exemplify the relation between form and function or use.

$\therefore \quad \therefore \quad$ In conversation courses, the students are exposed to natural language input, to realistic situations in which language forms are used in context. Usually, such conversations cover a wide range of topics dealing with the different situations of life. Therefore, a multiplicity of forms is deployed in realistic context. Courses in the 
language laboratory work towards the same effect and for the same purpose. In the language laboratory, students watch and listen to situations in which language forms are related to their functions. Furthermore, students are required to use forms in the context in which they occur.

In traditional grammar courses, students also have the chance to look at the communicative potential of language. An example is the use of modals. The same form or modal such as "could" can imply degrees of ability, probability, authority or politeness. Similarly, "must" may indicate obligation, duty or a certain kind of inference. Such areas are also touched upon with a theoretical orientation in semantics. The area of deontic and epistemic modality explores the issues of obligation and probability. Similarly, ambiguity is a semantic relation, which shows to students that the context is a deciding factor in determining the intended meaning. Both the linguistic and the pragmatic contexts are crucial - in this case for the disambiguation of an ambiguous utterance. 
As for literature courses, learners study drama, poetry fiction, criticism and culture. Three of the saforementioned courses are crucial for developing communicative competence, drama, fiction and poetry.

Dramatic discourse is the means by which character, action and setting are delineated. The dramatist's overt (explicit) intervention is manifested only in the case of stage directions. Otherwise, language is the prerogative of characters. Of particular importance is modern drama where as Tannen and Lakoff (1996:141) argue, "the writer's realization of his / her characters' styles represents a reality that has correlates, if not necessarily direct ones in more naturalistic texts." Thus the dialogue used in modern dramatic texts represents all the nuances of naturalistic discourse. This is why it is particularly suited for serving the communicative potential of language. Thus, different pragmatic functions are deployed in dramatic discourse.

$\therefore$ In the case of the novel and the short story, dialogue is also made use of. For example, in E.M. Forester's A passage to India, Buck (1997) examines the functions of utterances and how they cohere in large units of extended discourse. He shows (p.103) the 
function, development and purposeful evolution of sequences within utterances. This functional use of utterances gives the learners the opportunity to study linguistic form in use. Again form and function are inseparable in fiction. As in other text types, style is the deployment of meaning. Style, in other words, is the linguistic realization of meaning.

\section{Implications}

The first implication of this study is that interpretation does not depend on formal elements only. Discoursal and pragmatic elements are equally important. Language should be taught as form and function. Thus Hymes (1971:15) argues that communicative competence may include formal competence but extends to include knowledge of the rules "without which the rules of grammar would be useless."

Similarly, Canale and Swain (1980) insist that linguistic competence involves four areas of knowledge " . and skills (1) grammatical competence, sociolinguistic competence (3) discourse competence, and (4) strategic competence. Grammatical competence 
reflects knowledge of the linguistic code itself. Sociolinguistic competence addresses the extent to which ¿sentences are "produced and understood appropriately." Discourse competence enables writers to combine grammatical forms and meaning to achieve a unified text. strategic competence refers to the mastery of the communication strategies that enhance the effectiveness of communication. This is in accordance with Mir (1992:15) who offers the following suggestions to enhance the competence of learners:

(1) Making the learner aware of the variety of possible meanings of an utterance in context.

(2) Making the learner aware of the different levels of context.

(3) Aiding learners to assess contextual cues and to draw appropriate inferences about speakers' intentions.

In short, a teacher should not only help learners to understand forms in context, but he should also create situations which trigger students' interaction with the text. In this case learners can be presented with texts or dialogues that allow for a multiplicity of interpretations. Further more, a teacher can ask his students to create mini-dialogues that manifest more than one interpretation. 
A teaching method that fails to incorporate the communicative elements, that focuses merely on form should be complemented and supplemented by a communicative oriented method. Bardovi-Harlig's and Hartford's studies in ESL have shown that even highly proficient learners of English are often unable to use language appropriately in given contexts. Similarly, Wileland provided evidence that non-native speakers may never attain pragmatic competence. A concrete example is Di Pietro's strategic interaction, which deals with language as a set of scenarios. In these scenarios, Di Pietro (1987:8) believes that "we should be more realistic and look for ways in which lack of information or uncertainty about the intentions of others can motivate people to use the target language skillfully." Di Pietro continues to argue that the scenarios should be especially effective in "promoting learners to interact with each other without the full knowledge of what each is trying to say." The ability of learners to interpret and disambiguate becomes necessary in this case.

The second implication of this study is that listening and reading are far from being passive skills. 
Listeners and readers participate with speakers and writers in order to create meaning. As Savignon 1993:35) has cogently put it, "today listeners and readers are no longer regarded as passive. They are seen as active participants in the negotiation of meaning." The terms that best represent what happens in the act of listening and reading are Interpretation, expression and negotiation of meaning. Examining language from a communicative perspective means, as Savignon argues "the analysis of learner expression and negotiation." In this case, learners' pragmatic competence is developed and enhanced.

The third implication of this study is that courses in theoretical linguistics should not focus merely on formal analysis to the exclusion of meaning oriented courses like semantics and pragmatics. In some universities up till now, phonetics, morphology and syntax still occupy the major part of the syllabus of language courses. : Semantics and pragmatics are considered outside the * realm of a linguistic model. This is why they do not receive equal attention. It is the third implication of this study that semantics and pragmatics should be considered as important as other courses in linguistics, 
and hence as part of a linguistic model. Moreover, courses in semantics and pragmatics should not overlook concrete examples that illustrate the functional use of language. For example, students should be taught the notion that the same form can serve more than one communicative or discourse function. To be more concrete, students should be made aware of the fact that the question form for example can be indeterminate or ambiguous in that it can be used as a request, an order, an excuse, etc. Similarly, Mir (1992:15) suggests that teachers should aid learners in acquiring the ability to assess contextual clues and to draw appropriate inferences about speakers' intentions

Likewise, courses in literature should not only focus on the informational content but also on the linguistic dimension. In this case, the gap between language and literature can be bridged. Literature is usually thought of as "language at its best." Hence literature is a rich context for the strategic use of language. Literary discourse in this sense is functional, locus for both form and function to be related. A passage of literary discourse should be analyzed in terms of . speech acts. A concrete example is Tolba (1995) who. 
analyses a fragment of discourse from Dickens' Great Expectations showing that one character's utterances scan relate to directives and commissives while another " character can use assertives more frequently. Using the aforementioned analysis as a model, students can study a scene from a play or a chapter in a novel and analyze utterances accordingly. In this case, students' pragmatic skills are practiced. It is worth mentioning in this context, as Di Pietro repeatedly argues, that learners can achieve both communicative and grammatical skills when forms are operating in situations.

\section{Notes}

(1) See also Spolsky (1980) for a more elaborate argument.

(2) See Olshtain, E. and S. Blum-Kulka (1985) for a more elaborate argument.

(3)

See also Hudson et al., (1992,1995).

(4)

- Di Pietro discusses several types of ambiguity: structural, transactional and interactive. Interactive ambiguity relates to "how each interacting party perceives the roles being played by others." Each type of ambiguity "fits into a particular dimension of language." Structural ambiguity is the dimension of information exchange and transactional and interactive ambiguity is the dimension of transaction and interaction. 


\section{Works Cited}

Bachman, L.F. (1989) "Language testing- SLA Research Interfaces," Annual Review of Applied Linguistics.

........... (1990) Fundamental Considerations in Language Testing, Oxford: O.U.P.

Bardovi-Harlig, K. and Hartford, B: (1990) Congruence in Native and Non-native Conversations, Language Learning, 40,467501.

Blakemore, D. (1992) Understanding Utterances, London : Blackwell.

Bouton Lawrence F. (1988) A crosș- cultural study of the ability to interpret implicatures in English, World Englishes, vol.7,no.2.pp.18397 .

(1989) So they got the message, but how did they get it? IDEAL, vol. 4.pp.11949. 
(1992) "The Interpretation of Implicature in English by NNS: Does It Come Automatically - Without Being Explicitly Taught?" in Bouton and Y. Kachru (eds.) Pragmatics and Language Learning, Vol, .3 , U. of Illinois.

Brumfit, C. (1994) Communicative Methodology in Language Teaching: The roles of Fluency and Accuracy, Cambridge, C.U.P.

Buck, R.A. (1997) "Towards an extended Theory of Face Action: Analyzing Dialogue in E.M. Forester's A Passage to India," Journal of Pragmatics, 27, 83-106.

Canale, M. (1983) "From Communicative Competence to Communicative Language Performance," in J.Richards and R. Schmidt (eds.), Language and Communication, New York: Longman. and Swain, M. ( 1980$)$ "Theoretical Bases of Communicative approaches to 
Second Language Teaching and Testing," Applied Linguistics, Vol.1, 1-47.

Coates, J (1983) The Semantics of Modal Auxiliaries, London: Croom Helm.

Croft, K. (1980) (ed.) Readings on English as a second Language, Canada: Little, Brown and Company.

Day, E. and S.M. Shapson (1991) "Integrating Formal and Functional Approaches to Language Teaching in French Immersion," Language Learning, Vol.41, No.1.

Di Pietro, R. (1988) Strategic Interaction: Learning Languages Through Scenarios, London: Edward Arnold.

Fouly, K.A., Bachman, L.F. and G.A Cziko (1990) "The Divisibility of Language Competence: A confirmatory Approach," Language Learning, 40:1, pp.1-21. 
Green, G.M. (1989) Pragmatics and Natural Language Understanding, Hillsdale, N.J.: Lawrence Erlbaum.

Grice, P. (1975) "Logic and Conversation," in P. Cole and J. Morgan (eds.) Syntax and Semantics, Vol. 9, New York: Academic Press.

Hicks, S. (1992) "Linguistic and Pragmatic competence: their relationship in the overall competence of the language learner," Pragmatics and Language Learning, Monograph Series, Vol .3.

Holmes, J. (1989) "Sex Differences in Apologies: One Aspect of Communicative Competence," Applied Linguistics, Vol.10, No.2.

Hudson, T., and J. Brown (1992) A Framework for Testing Cross-cultural Pragmatics. Technical report, Honolulu: University of Hawaii.

(1995) Developing

Prototypic Measures of cross-cultural 
Pragmatics, Technical report, Honolulu: University of Hawaii.

Hymes, D. (1971) On Communicative Competence, Philadelphia, University of Philadelphia Press.

Littlewood, W. (1981) Communicative language Teaching, Cambridge, C.U.P.

Mir. M. (1992) "Do we All Apologize the Same? An Empirical Study on the Act of Apologizing by Spanish Speakers Learning English" in Bouton et al. (eds.) Pragmatics and Language Learning.

Olshtain, E. and S. Blum-Kulka (1985) "Crosscultural Pragmatics and the testing of Communicative Competence," Language Testing, 2:16-30.

Rizk.S.(1997) "Apology in English Among Arab Non-Native Speakers of English, "Journal of the Faculty of Education (Literary Section, 
Vol.3, No 11, 1997.

- Sasaki, M.(1998) "Investigating EFL Students' Production of speech Acts : A comparison of production Questionnaires and Role Plays, “Journal Of Pragmatics, 30, 457-484.

Spolsky, B. (1980) "What Does It mean to know a Language in Croft (ed.)

Savignon, S. (1993) "Communicative Language Teachings," in Silberstein, S. (ed.) State of the Art TESOL Essays.

Scarcella, R. and L. Rebecca (1992) The Tapestry of Language Learning, Boston, Ma.: Heinle and Heinle pub.

: = Sperber, D. and D. Wilson (1986) Relevance: Communication and Cognition, Cambridge, Ma.: H.U.P.

Stubbs, M. (1983) Discourse Analysis, London: Blackwell. 
Tannen, D. and R. Lakoff (1996) Conversation strategy and Metastrategy in Pragmatic Theory," in Tannen, D. Gender and Discourse, Oxford: O.U.P.

Thomas, J. (1988) "Complex Illocutionary Acts and the Analysis of Discourse," Paper Given at the Second Finish Seminar on Discourse Analysis, Oulu, September 1988.

(1995) Meaning in Interacting, London Blackwell:

Tolba, N. (1995) "The speech Act theory's Explanatory power in understanding Fictional Dialogue," Dialogues of languages and English language Education, CDELT: Ain Shams University.

Wieland, M. (1990) Politeness-Based Misunderstandings in Conversations between Native Speakers of French and American Advanced Learners of French. Unpublished 
Doctoral Dissertation, Indiana University.

Yule, G. (1996) Pragmatics, Oxford. O.U.P. 


\section{Appendix \\ (Indirectness interpretation test) \\ Test: part one \\ Pragmatic Ambivalence}

Read the following situations or mini-dialogues and choose the response you think most appropriate.

I

1- Teacher and students are in the classroom. It is $40^{\circ} \mathrm{C}$. Teacher, (Looking at the window) says: "isn't the room so hot?"

a- $\mathrm{St}_{1} \quad$ : Yes, sir, it is hot .

b- $\mathrm{St}_{2}$ : Yes, you are right, sir .

c- $\mathrm{St}_{3}$ : (Goes and opens the window).

2-Mother complains to children that the room is dark. Looking at the light switcher, she says "isn't the room dark?"

a- Jim : well . It is sunset time, mom.

b- John : O.K. Mom . I'll turn on the light.

c- Jim : yes, you are right. It is very dark.

3-It is cold outside. Mother says to children "do you mind closing the window?

a- Jim : Yes, of course, I can .

b- John : No, I don't

c- Tim : (Moving to close it ) No, I don't . 
4- It is dusty and dirty in the room: Mother says to the children " isn't it dirty here?" Oh! Why is your room so dirty kids?

a- Jim : O.K. I'll clean it, mom .

b- John : It is not dirty. There are just many things on the floor, mom.

c- Tim : Yes, it is very dirty .

5- John invites William, Jim, and Tim to go out to McDonald's. John discovers that he has no money and says " 1 have forgotten my wallet".

a- Jim : O.K. I'll lend you money .

b- William : Do you keep your money in a wallet?

c- Tim : Have you lost your money ?

6- John says to William " can you tell me the time? a- John is only asking if William can tell the time b- John wants to borrow his friend's watch. c-John wants to know the time.

7-Mother says to her sons " isn't there a nice movie on the T.V now?

a-William: Yes. You are right, mom.

b-Robert : yes, $\mathrm{I}$ am sure there is a movie on T.V now. c-Mike : O.K. I'll turn on the T.V

8-A teacher wants a child to pick up a towel and hang it on a rail. The teacher says to Jimmy "some one might step on the 
towel Jimmy. Would you like to pick up the towel for me?

a- Yes, Some one might.

b- No, Nobody should.

c- O.K. I'll pick it up.

9- A child comes back from school and says to his mother "I'm hungry mom. I feel like eating.

a- The child is describing his feeling.

b- The child is requesting food.

c- The child is asking about the types of food they have at home.

10- John and his friends are coming back from school. John says to Jim "I borrowed too many books from the library today. They are too heavy."

a. Jimmy: No, the books are not too heavy.

b. Tom: Really?

C. (William helps John and carries some books).

\section{II}

1- Father is busy fixing the car. John asks his father " can I have a dollar?" Father replies "see what 1 am doing?"

a- Father is finding an excuse.

b- Father wants the boy to help him.

c- Father tells the boy to watch him while he is fixing the car. 
2- John wants Jim to give him a ride to the airport at six o'clock. Jim says to John " 1 have to be at work at this time.

a- John is merely reporting what he is doing.

- b- Jim is seeking an excuse.

3- Mary wants to visit Helen at six. At this time Helen will be at the dentist's. So, she says to Mary "I'll be at the dentist's at six."

a- Helen is finding an excuse.

b- Helen is only describing what she is doing.

4-Mary is a police investigator. John is her boss. She is bombarding him with questions. He sounds embarrassed. So, he says to her "I can't answer you right now."

a- John has no answer at all.

b- John is making an excuse.

5- John asks Jim to go with him to the cinema. Jim wants to go home and study. So he says, "there are no good movies on show."

a- Jim wants to see a good movie.

b- Jim is making an excuse.

-6- John wants to borrow Mary's books. Mary says "but I think they are over-due."

a. Mary is offering an excuse.

b. Mary is merely reporting. 
7- John wants to borrow a cigarette from Jim. Jim says "the Surgeon General warns against smoking."

a. Jim believes that smoking is dangerous.

b. Jim is making an excuse.

8- William is sitting at a coffee shop. The waiter gets him a cup of coffee. William says "there isn't any sugar in it." The waiter answers "didn't you tell me before that you are diabetic?"

a- The waiter is making an excuse.

b- The waiter is only making a statement.

9- Student says to a professor "do you have a minute to look at my paper? Professor answers "right now." Is it typed?"

a- professor is merely asking a question.

b- Professor is seeking an excuse

10- Sara asks her father to buy her a new coat. He says "but the winter is almost over."

a- Father is making a statement about the weather.

b- He is making an excuse.

\section{III}

1. John is buying a shirt from a shop. The shop assistant says to : him "can I help you?" John might say:
a. Yes, you can.
b. Yes 1 need a blue shirt.
c. Can you? 
2- John says to Tim "Are you coming to have tea with us this cvening." Tim says in reply "I am afraid not." Tim intends to say:

a- I will not be able to.

b- I am sure 1 will come.

c- I am not afraid to have tea with you.

3- John is sitting in a coffee - shop asking for tea. The bar- man says "here you are." This means:

a- At last 1 have met you.

b- Are you still waiting?

c- Please take it.

4- John calls Mary on the phone and says to her "we've got a new coffee-maker, which makes coffee taste better." Mary replies "if I've got the time."

a- John is only describing the function of the coffee maker.

b- John is inviting her to coffee.

5- John says to Jim "do you spend the summer in Alexandria?

" We've got a nice apartment looking over the sea."

- a- John is inviting Jim to go and spend the summer with him in Alex.

b- John is only asking if Jim stays in Alex in the summer. 
6- An air-hostess asks a passenger "have you found your seat?" "No I'm still looking for it," he answers.

a- The air - hostess is merely asking a question.

b- The air - hostess is offering to help the passenger.

7- John is looking from the balcony. He sees Jim. Jim is fixing his car. John asks, "do you want me to have a look at the engine?"

a- John is asking Jim a question about his car.

b- John is offering to help Jim.

8- Mary is having a party. She is planning to bake different kinds of sweets. Jane says to her "I make very nice cookies."

a- Jane is only reporting what she can do.

b- Jane is offering to help Mary.

9- Some friends were invited for dinner in Mary's house. They are sitting in the living room. Mary (calling at the door) . Ready?

a- She wants them to move and start eating.

b-She asks them if she can prepare the meal for them.

c- She tells them that she is ready to start preparing the meal.

10- John visits Jim. It is lunch time. The family is eating. Jim's mother says to John "I make very nice meat balls."

a- Mother is only praising her cooking.

b-Mother is inviting John to eat with the family. 
1- A family is sleeping. There is smoke. Father says, "there must be a fire."
a. John: You're right dad. This is smoke.
b. Tim: Yes dad. There is smoke.
c. Jim: come on! Let us put it out.

2- A family is about to sleep. The mother says "it is freezing cold here." Don't you feel the cold?"
a. John: Yes, we do.
b. Tim: You're right dear.
c. Jim: O.K. I'll go and turn on the heating system.

3- Teacher and students are in the classroom. The teacher says to his students " can't you hear something falling?"

a-St $t_{1}$ : Yes, I can hear something falling.

b-St ${ }_{2}$ : It's true . I can hear it well.

c-St 3 : let me see! (He opens the door and goes out.) I'Il see

4- The family is sitting together. Mother says cold air is coming $\checkmark$ from under the door.

a. John: Yes, I feel it very much.

b. Jim: let us put a mat under the door.

c. Tim: You are right. It is very cold auntie

5- John and Mary are driving on the Highway. John says to 
Mary "are you wearing your seat - belt."

a- John is asking if Mary is wearing her seat - belt.

b- John is warning Mary.

6- Students are talking while teacher is explaining. Teacher says to them "keep talking and you will stay in class after lunch."

a- Teacher is asking students to talk.

b- Teacher is warning students.

7- John and Mary are in the former's car. John drives rapidly. Mary tells John that there is a pump ahead.

a- Mary is cautioning John.

b- Mary is only describing the road.

8- John and Mary are at home. John says to Mary "There is a rat in the room" Mary panics.

a- John is merely talking about what is happening.

b- John is warning Mary.

9- John and Jim are taking the bus to school. John says to Jim "there is a pick-pocket in the bus."

a- John is warning Jim.

b- John is saying where the pick - pocket is.

10- John and Jim are about to write a paper on the computer. Jim says "there is a virus in the computer,"

a- Jim is only talking about the virus.

b- Jim is issuing a warning. 


\section{Part Two: Implicature}

1. A professor was returning to a student the paper he submitted last weak. The student asked "what do you think of my paper ?" The professor answered, "oh, it is well typed."
A: the professor likes the paper.
B: the professor does not like the paper.
c- the professor admires the format of the paper

2- John bought a suit. When he asked Mary if she liked it, she said "I like the tie better."
$\mathrm{a}$ : Mary liked the suit.
B : she thought the tie matches the suit .
$\mathrm{C}$ : Mary did not like the suit .

3- Mother served the family a hot meal. When the husband was asked how much he liked the meal, he replied " 1 would prefer it cold."
a. The husband liked the food.
b. He did not like it very much.

4- John wants his father to buy him a car. His father tells him : "sfohn, cars are expensive to run."

- a- father wants to buy the car.

b- Father is hesitant to buy the car.

5- One day, a man met a rabbit running away from a village. The man asked the rabbit "why are you running away little rabbit?" 
The rabbit was trembling and kept looking around and said because there is a revolution in this village and they kill all old camels. The man was surprised and said but you are neither camel nor old. The rabbit said until I prove that they will have killed me."

a- the author is revolutionary.

b- the author is anti- revolutionary.

6- John asks Jim to open the door, Jim says "I'm eating."

a. Jim wants to open the door.

b. Jim implies that he is doing something.

7-The waitress says to John "ready to eat, not before I wash my hands."

a. John is ready to eat.

b. John wants to do something before he eats.

8- John asks Mary "do you like tea?" Mary answers "it has a lot of caffeine."

a- Mary wants to drink tea.

b- Mary prefers another drink.

9- John says to Jim "do you like to fly to N.Y.?" Jim answers "cars are safer.

a- Jim prefers to fly.

b- Jim prefers to drive.

10- John "we're going to have fish for dinner." 
Tom : Again!

a- Tom likes to eat fish again.

b-Tom does not like to eat fish .

c- Tom wants John to repeat what he said.

- 11- John asks Mary "do you love plays and movies?" she answers "I love to go to the theatre."

a- Mary likes to go to the theatre and the cinema .

b- Mary likes only the theatre.

12-Mary asks "John do you love your wife?" John answers "marriage is marriage."

a- John loves his wife very much.

b- John does not reveal a true love for her.

13- When asked if he drinks Pepsi, John answers "do dogs drink vodka?"

a- John likes to drink Pepsi.

b- John does not like Pepsi.

14- When asked if dogs bite, John answers "do cats meow?" a- John answered affirmatively.

- b-John answered negatively

15- when asked if he loves Indians, John answers "do Jews like Hitler?"

a- John answered negatively.

b- John answered affirmatively. 
16-John says to Jim "have you been to England and France." Him says in reply "I have been to England.

a. Jim has visited both England and France.

b. Jim has visited England only.

17- John asks Jim "Isn't your car expensive and nice?" Jim says answers "it is nice."

a- Jim is only implying that his car is nice.

b- Jim is confirming that his car is nice and expensive.

18- John is asking his father "is my birthday today?" His father answers "many happy returns."

a- Father is implying that it is his birthday.

b- Father is denying that it is his birthday.

19- John says to Mary "Let us have lunch." Mary replies "It is not lunch time yet."

a- Mary is ready to have lunch.

b- Mary is not ready to have lunch yet.

20- Sami is an Egyptian student living in America. He wants to : marry Mary, an American girl. When he told her father that he wanted to marry Mary, her father said "I'd prefer an AngloAmerican."

a- Mary's father was happy to see his daughter marrying an Egyptian.

b- The father was hesitant. 